„merking, dat deze beslissing eerst gevolgen heeft van heden af."

Wij hopen, dat de hierboven aangehaalde ,overwegingen'” van den Raad van Beroep van Amsterdam alsnog invloed zullen uitoefenen op de houding der R. V. B. en zij daarin aanleiding moge vinden, om niet dan bij uitzondering van een accountant te verklaren, dat hij geen bedrijf uitoefent en daardoor diens personeel uit te sluiten van een verzekering, waarop het naar de bedoeling der wet toch ongetwijfeld recht kan doen gelden.

Wij achten het niet misplaatst in dit verband er op te wijzen, dat de gemeentelijke fiscus hier en elders bij den aanslag in de zakelijke belasting op het bedrijf blijkbaar in het minst niet wordt geplaagd door eenigen twijfel over de vraag of de accountant een bedrijf uitoefent, doch hun allen onvervaard een aunslag zendt.

\section{VIJFTIENDE ACCOUNTANTSDAG}

Zaterdag 29 September 11 . werd in het hotel „De Oude Doelen" te 's-Gravenhage de Vijftiende Accountantsdag gehouden, georganiseerd door het Nederlandsch Instituut van Accounlants. De vergatering was ook ditmaal weder druk bezocht, de referaten werden met aandacht gevolgd en gaven aanleiding tot een druk debat. De Voolzitter, de heer C. van Uden, opende de bijeenkomst, die te $10.30 \mathrm{v.m}$. aanving, met het uitspreken van de volgende rede.

\section{Rede van den Voorzitter}

Namens het Bestuur van het Nederlandsch Institunt varAccountants heet $\mathrm{Ik} \mathrm{U}$ allen hartelijk welkom op dezen, onzen Ioden Accountantsdag.

Dit woord van welkom gaat in het bijzonder uit tot de leden van den Hoogen Radad der Nederlanden, en verdere leden van de Rechterlijke Macht, de Ieden van de Staten-Generaal, de leden vall de Algemeene Rekenkamer, den vertegenwoordiger. van de Kanner' van Koophandel te 's Gravenhagen en van die te Rotterdan, die door hunne aanwezieheid blijk van belangstelling geven,

tot Professor Mr. E. M. Meyers, die aanstonds een voordracht zal houden over "Aansprakelijkheid en décharge van Directeuren van Naamlooze Vennootschappen",

en tot den Heer Ir, D. H. Stigter, Voorzitter van de Orde van Nederlandsche Raadgevende Ingenicurs, en ons medelid, den heer $H$. $K$. Reder, die hedenmiddag voor ons zullen inleiden het onderwerp: „De grondslagen der samenwerking tusschen raadgevend ingenieur en accountant".

Alvorens het woord te verleenen aan Prof. Meyers, zij het mij vergund te wijzen op het heugelijke feit, dat deze accountantsdag valt in de maand, waurin onze gec̈erbicdigde Vorstin haar zilveren Regeeringsjubileum viert.

Het Nederlandsch Instituut van Accountants sluit zich gaarne aan bij de hulde, aan onze koningin allerwege gebracht. Het Bestuur vertrouwt in den geest der leden van het Instituut te handelen door hedenmorgen een telegram van hulde aan Hare Majesteit te zenden. (applaus.)
De geschiedenis vall de accountancy in Nederland valt nagenoeg samen met de zoo juist afgesloten regeeringsperiode. Immers bij de troonsbestijging onzer V'orstin bestond het Nederlundsch Institunt van Accountants, opgericht 1 Januari 1895, nauwelijks drie jaar, en het mag gezegd worden, dat met de oprichting van ons Instituut de geschiedenis van de Accountancy in Nederland is aangevangen, nadat enkele pioniers door hun persoonlijk werk het bestaansrecht van den accountant hadden aangetoond.

De vraag of de accountaney in de laatste 25 jaren voor ons land van beteekenis is geweest. mag zeker bevestigend worden beantwoord.

Aanvankelijk was nauwelijks van algemeene bekendheid welke taak de accountant in het maatschappelijk leven had te vervullen, zijne diensten als controlecrend en adviseerend deskundige op comptabel gebied werden met zekeren schroom door particuliere ondernemingen op het gebied van handel en nijverheid aanvaard; thans is voor jeder het bestaan van den accountant even vanzelf sprekend als b.v. dat van den geneeslicer, en is hij naast deskundige op boekhoudkundig gebied geworden tot adviseur in aangelegenheden van bedrijfseconomischen aard. Niet slechts particulieren maken van zijne diensten gebruik; de regelmatige benoeningen, o.a. als deskundige bij aanvragen om suiséance van betaling, bewijzen, dat ook de Rechterlijke Macht zijne diensten waardeert, terwijl de Overheid bovendien de beteekenis van de accountancy heeft doen uitkomen door de amstelling van ambtenaren-accountants bij vele takken van openbar bestuur; ik noem slechts den Accountantsdienst der Directe Belastingen, het Bureau der Statistiek van Voortbrenging en Verbruik, en de Gouvernementshedrijven in Nederlandsch-Indië.

Voorts moge ik hier nog wijzen op de werkzaamheden gedurende de oorlogsjaren door accountants verricht voor Regeerings-commissies en Regeerings-Bureaux, de N. O. T. en verschillende Consulaten, welke werkzaamheden zeker niet zonder beteekenis voor ous land zijn geweest.

1)at de accountancy mag bogen op een gestadige ontwikkeling is ongetwijfeld niet weinig toc te schrijven aall de zorg, welke het Nederlandsch Institunt van Accountants sinds zijne oprichting steeds heeft gewijd aan de stelselmatige studie en aan de opleiding voor het beroep. Hierdoor toch werd zoowel direct als indirect de aandacht gevestigd op de wetenschappelijke zijde van ons beroep, wat o.a. tot gevolg had, dat bij verschillende inrichtingen van Hooger Onderwijs leerstoelen aan accountants werden toevertrouwd. Zoo werd in 1909 aan de Techliische Hoogeschool te Delft, en in 1913, bij de oprichting van de Nederlandsche Handelshoogeschool te Rotterdam een accountant benoemd tot Buitengewoon Hooglceraar in de Bedrijfsleer; aan laatstgenoemde school werd bovendien in 1915 en in 1921 cen accountant benoemd tot Hoogleeraar in de Bedrijfsleer en Rekeningwetenschap, terwijl in 1922, na de oprichting van de Faculteit der Handelswetenschappen aan de Gemeentelijke Universiteit te Amsterdam een accountant werd benoemd tot Hoogleeraar in de Bedrijfshuishoudkunde.

Moge dus al met voldoening worden teruggezien op hetgeen 
reeds werd bereikt, hier mag niet worden verzwegen, dat in cón bestaande loemte nog niet werd voorzien: een wettelijke regeling van het accountantsberoep kwam nog niet tot stand.

Tolgens artikel 1. der Statuten van het Instituut heeft dit o.a. ten doel te streven naar een wettelijke regeling van het beroep. Terecht heeft het Instituut reeds sinds de oprichting ingezien, dat slechts hierdoor op afdoende wijze de belangen van het publiek en van de bona--fide accountants kunnen worden beschermd, en de beunhazerij op het gebied der accountaney kan worden bestreden. De feiten hebben helaas bewezen tot welke teleurstellingen de uitoefening van het beroep door onbevoegden kan leiden.

Wel werd bij Koninklijk Isesluit van 16 Mei 1918 een Staatscommissie ingesteld, welke tot doel had na te gaan of - en zoo ja, op welke wijze - een wettelijke regeling van het handelsonderwijs en het accountantswezen behoorde te worden getroffen.

Deze commissie kwam tot ecn conclusie in bevestigenden zin; in het door haar uitgebrachte verslag dd. 31 December. 1920 was een ontwerp van wet tot regeling van het accountantswezen opgenomen. Nadat dit verslag openbaar was geniakt, werd van eenige werkzaamheid der regeering, om de wettelijke regeling tot stand te brengen, niets meer vernomen.

Het Bestuur van het Nederlandsch Instituut van Accountanls richtte daarom op 8 September 1922 een schrijven tot den Minister van Onderwijs, Kunsten en Wetenschappen, waarbij werd verzocht om enn spoedige afdoening dezer aangelegenheid te bevorderen. Op dit sehrijven mocht het Instiiuut op 11 November 1922 als antwoord de mededeeling ontvangen, dat de stukken tel'zake aan den Minister van Landhouw, Nijverheid en Handel a.i. waren overgedragen, met verzoek in overleg met den Ministel van Justitie te willen nagaan, welk gevolg aan het request van het Instituut ware te geven.

In de rede door den Minister vall Binnenlandsche zaken en Landbouw gehouden bij de sluiting van de zitting der StatenGeneraal op 15 dezer, liet Z.Exc. zich o.a. als volgt uit: „De ,finanticele nood dwong tot buitengewone mastregclen van kezuiniging en tot onthouding."

Ik vertrouw, dat dezc passus niet moet worden opgevat als een verklaring, waarom o.a. de wettelijke regeling van ons reroep alsnog achterwege bleef; het moet immers mogelijk zijn, bij een doelmatige verdeeling, de kosten, aan een wettelijke regeling van het accountantswezen verbonden, voor het Rijk tot een gering bedrag te beperken. Indien ergens, dan doet zich hier de gelegenheid voor, on, ondanks den finantieclen nood van het Rijk, de bemoeiingsfeer van de Overheid in het algemeen belang uit te breiden.

Ik spreek dan ook de hoop uit, dat spoedig van de Regeering een voorstel tot wettelijke regeling van het accountantswezen moge uitgaan, opdat het accountantswezen zich in de toekomst ten batc van de gemeenschap, op volkomen gezonde basis kan ontwikkelen.

(Wordt vervolgd.)

\section{LITERATUUR (') \\ Red. Dr. A. STERNHEIM}

(Bijdragen en mededeelingen zende men aan den Secretaris der Redactie)

\section{HET CREDIETONDERZOFK}

Als ieder speciaal onderzoek vereischt het credietonderzoeli een dubbele beschouwing, die van het technische en het bedrijfshuishoudkundig gedeelte. Het eerstbedoelde gedeelte zal zich uitsluitend bezighouden met de vraag hoe of de accountant de verantwoordelijkheid voor een bepaalde opdracht kan aanvaarden. Als algemeene regel dient naar onze meening daarbij aangenomen te worden dat alleen verantwoordelijkheid te dragen is op grond van een volledige in alle details doorgevocrde controle der administratie, doch lat modifacatics toelaatbaar zijn voor zoover een bepaalde opdracht dit mogelijk maakt. Dergelijke modificaties zijn in het algemeen zeer gevaarlijk, in het bijzonder bij het credietonderzoek wanneer het in een roor den accountant niet beliende ziak bij een hem onbckenden cliënt moet geschieden.

De bedoeling van dit opstel is in het bijzonder om na te gaan wat in enkele vakwerken over het bedrifshuishoudkun. dig gedeelte van dit onderzoek workt betoogd. De belangrijkheid van het credietonderzoek makt een speciale beschouwing van de bedrijfshuishouding noodig on te kummen vaststellen wat de oorzaak der eredietbehoefte is en van de gerechtvaardigheid der aanvrage in verband met de algemeene kapitaalpositie. Het opspuren der spanningsperioden in productie en verkool) (wat bij industricele ondernemingen verschillend kan zijn) is op zichzelf een zee ${ }^{2}$ moeilijk werk en kan niet steeds vervangen worden door bo drijfs-empirie. De banken plegen uitsluitend met deze lantste te werk te gaan en dit is verioedelijk een der redenen dat men van de cens gegeven credieten - tenzij ze emissie-rijp kunnen gemaakt worden of voor speciale transacties dienen

niet meer afkomt, terwijl toch in den grond der zaak het bankierscrediet uitsluitend dienen mag om spanningsperiodeu (productic- of erediettermijn) te overbluggen. ${ }^{2}$ )

De wijze waalop de spanningsperiode gezocht moet worden kummen wij hier buiten heschouwing laten.

Indachtig dat de bedrijfshuishoudkunde een drieledige taak

1) Het is de bedoeling in deze rubriek na te gaan wat over bopaalde onderwerpen in de litteratur aanwezig is.

2) Mr. W. M. Westerman "De Concentratie in het Bankwezen" (1919) pag. 245 met betrekking tot het verschil tusschen Betriebs- en Anlagecrediet ,Het is juist onder die omstandigheden, dat het bankcrediet anuvullend kan optreden en daardoor een leemte in de credietorganisatie, welke van invloed zou kunnen zijn op den regelmatig . 1 gang van het productieproces, ondervangen".

De Bankpolitiek door Mr. Dr. G. M. Verrijn Stuart, pag. 15, ten aanzien van het verschil tusschen deposito- en algemeene banken: „Mct name clenken wij hier aan het industriëele crediet dat gevraagd wordt gedurende de periode dat in de industrie loonen en grondstoffen mocten worden betaald, zonder dat daartegenover onmiddellijke inkomsten uit den verkoop van producten kunnen worden gesteld. Ook lang hasdelscrediet wordt door deze banken wel verleend". 